\title{
The Contribution of Dietary Magnesium in Farm Animals and Human Nutrition
}

\author{
Luciano Pinotti $^{1,2, * \mathbb{D}}$, Michele Manoni ${ }^{1} \mathbb{D}$, Luca Ferrari ${ }^{1}$, Marco Tretola ${ }^{1,3} \mathbb{D}$, Roberta Cazzola ${ }^{4}$ and Ian Givens ${ }^{5}$ \\ 1 Department of Health, Animal Science and Food Safety (VESPA), Università di Milano, 20133 Milan, Italy; \\ michele.manoni@unimi.it (M.M.); luca.ferrari2@unimi.it (L.F.); marco.tretola@agroscope.admin.ch (M.T.) \\ 2 CRC I-WE (Coordinating Research Centre: Innovation for Well-Being and Environment), \\ Università di Milano, 20133 Milan, Italy \\ 3 Agroscope, Institute for Livestock Sciences, 1725 Posieux, Switzerland \\ 4 Department of Biomedical and Clinical Sciences "L. Sacco", Università di Milano, 20157 Milan, Italy; \\ roberta.cazzola@unimi.it \\ 5 Institute for Food, Nutrition and Health, University of Reading, Reading RG6 6AR, UK; \\ d.i.givens@reading.ac.uk \\ * Correspondence: luciano.pinotti@unimi.it; Tel.: +39-02-503-15742
}

Citation: Pinotti, L.; Manoni, M.; Ferrari, L.; Tretola, M.; Cazzola, R.; Givens, I. The Contribution of Dietary Magnesium in Farm Animals and Human Nutrition. Nutrients 2021, 13, 509. https://doi.org/10.3390/ nu13020509

Academic Editor: Mario Barbagallo

Received: 29 December 2020

Accepted: 1 February 2021

Published: 4 February 2021

Publisher's Note: MDPI stays neutral with regard to jurisdictional claims in published maps and institutional affiliations.

Copyright: (c) 2021 by the authors. Licensee MDPI, Basel, Switzerland. This article is an open access article distributed under the terms and conditions of the Creative Commons Attribution (CC BY) license (https:// creativecommons.org/licenses/by/ $4.0 /)$.

\begin{abstract}
Magnesium (Mg) is a mineral that plays an essential role as cofactor of more than 300 enzymes. $\mathrm{Mg}$ in farm animals' and human nutrition is recommended to avoid $\mathrm{Mg}$ deficiency, ensure adequate growth and health maintenance. Mg supplementation above the estimated minimum requirements is the best practice to improve farm animals' performances (fertility and yield) and food products' quality, since the performance of farm animals has grown in recent decades. $\mathrm{Mg}$ supplementation in pigs increases meat quality and sows' fertility; in poultry, it helps to avoid deficiency-related health conditions and to improve meat quality and egg production by laying hens; in dairy cows, it serves to avoid grass tetany and milk fever, two conditions related to hypomagnesaemia, and to support their growth. Thus, $\mathrm{Mg}$ supplementation increases food products' quality and prevents $\mathrm{Mg}$ deficiency in farm animals, ensuring an adequate $\mathrm{Mg}$ content in animal-source food. These latter are excellent $\mathrm{Mg}$ sources in human diets. Sub-optimal Mg intake by humans has several implications in bone development, muscle function, and health maintenance. This review summarizes the main knowledge about $\mathrm{Mg}$ in farm animals and in human nutrition.
\end{abstract}

Keywords: magnesium supplementation; animal nutrition; livestock; magnesium deficiency; magnesium in human nutrition; animal-derived foods

\section{Introduction}

The average content of $\mathrm{Mg}$ in the body of most animals is $\sim 0.4 \mathrm{~g} \mathrm{Mg}$ per kilogram of body weight [1]. In the human body, the total $\mathrm{Mg}$ concentration is around $\sim 20 \mathrm{mmol} / \mathrm{kg}$ of fat-free tissue. This value corresponds to $\sim 24 \mathrm{~g}$ of total $\mathrm{Mg}$ in an average $70 \mathrm{~kg}$ adult with $20 \%(w / w)$ fat [2,3]. In comparison, the body content of calcium is $1000 \mathrm{~g}$ (i.e., 42 times greater than the body content of $\mathrm{Mg}$ ) [4]. Assuming that a similar relationship exists for other mammals, the total body $\mathrm{Mg}^{2+}$ of a cow with a body weight of $700 \mathrm{~kg}$ should be roughly $455 \mathrm{~g}$, of which approximately $320 \mathrm{~g}$ would be skeletal (approximately $60-70 \%$ of $\mathrm{Mg}$ is located in the skeleton), about $130 \mathrm{~g}$ intracellular, while only about $4-5 \mathrm{~g}$ would be found in the total extra-cellular space (i.e., $35 \%$ is distributed in soft tissue and extracellular fluid) $[4,5]$. For the same cow the calcium content is between $7-9.6 \mathrm{~kg}$, which means 21 times greater than the body content of $\mathrm{Mg}$.

However, $\mathrm{Mg}$ is important for many functions in animals' body and its deficiency results in several dysfunctions. Accordingly, as reported for humans, also in the case of farm animals $\mathrm{Mg}$ requirements and recommendations have been defined.

In light of this, the aims of the present review are to: (i) provide an overview of $\mathrm{Mg}$ requirements and recommendations in farm animals; (ii) describe the main effects of $\mathrm{Mg}$ 
supplementation on growth, reproduction, health and product quality in farm animals; (iii) describe the potential contribution of food of animal origin to the $\mathrm{Mg}$ intake in humans; (iv) discuss the consequences on humans' health of sub-optimal Mg intake, which are rather different to those in farm animals.

\section{Mg in Farm Animals' Diet}

Mineral nutrients are essential for adequate growth, productivity, and health of all food producing animals. Among minerals, $\mathrm{Mg}$ is considered one of the seven macro minerals that are essentials in farm animal diets. These are: calcium $(\mathrm{Ca})$, phosphorus $(\mathrm{P})$, magnesium $(\mathrm{Mg})$, sulphur $(\mathrm{S})$, sodium $(\mathrm{Na})$, chlorine $(\mathrm{Cl})$, and potassium $(\mathrm{K})$. Many factors can affect mineral requirements of farm animals, namely: species, age, physiological stage, and performance (average daily gain, milk yield, egg yield, etc.). The performance and efficacy - expressed as feed conversion rate (FCR, $\mathrm{kg}$ feed per $\mathrm{kg}$ of animal product) —of modern high producing farm animals has increased dramatically over the past decades (Table 1), which may contribute to the changes in nutritional requirements of food producing animals. Although the requirement for $\mathrm{Mg}$ can be met by common feed ingredients in animal diets, research and practice have shown benefits from supplementing Mg above the estimated minimum requirements in several food producing animals like pigs, poultry, and cows (as farm ruminants' representative). The practice of supplementing feedstuffs with $\mathrm{Mg}$ is widely used, with the primary aim to avoid $\mathrm{Mg}$ deficiency and then to improve animal performance (fertility and yield) and sometimes products' quality [4-10].

Table 1. Production efficiency trend: feed conversion rate (FCR), $\mathrm{kg}$ feed per $\mathrm{kg}$ of animal product. Adapted from [11,12].

\begin{tabular}{cccc}
\hline Product & $\begin{array}{c}\mathbf{1 9 6 0 - 1 9 7 0} \\
\text { FCR }\end{array}$ & $\begin{array}{c}\text { Today } \\
\text { FCR }\end{array}$ & Efficiency Improvement \\
\hline Poultry meat & 4.5 & 1.9 & $57 \%$ \\
\hline Turkey meat & 6.0 & 2.5 & $58 \%$ \\
\hline Eggs & 4.3 & 2.1 & $51 \%$ \\
\hline Milk & 2.2 & 0.7 & $68 \%$ \\
\hline Pig $(100 \mathrm{~kg})$ meat & 4.3 & 2.7 & $37 \%$ \\
\hline Beef $(400-700 \mathrm{~kg})$ & 9 & 7 & $22 \%$ \\
\hline Mean & 5.05 & 2.81 & $49 \%$ \\
\hline
\end{tabular}

As for other farm animal species, $\mathrm{Mg}$ is a key dietary element and it is essential for animal growth and survival. Notably, it has essential functions in cellular metabolism and bone development [2,13]. In terms of supplementation, oxide, carbonate and sulphate are all sources of highly available $\mathrm{Mg}$ for farm animals [14]. Generally, $\mathrm{Mg}$ oxide ( $\mathrm{MgO})$ is the most used and the highest $\mathrm{Mg}$-concentration mineral source available as an animal feed ingredient (Table 2). Magnesium oxide usually guarantees an adequate absorption of $\mathrm{Mg}$ ions. Not all sources of $\mathrm{MgO}$ are equal to the task of providing efficiently the necessary $\mathrm{Mg}^{2+}$ ion amount to a living organism. Solubility, reactivity, and bioavailability are all characteristics that differ from one $\mathrm{MgO}$ product to another [4]. The mineral feed bioavailability is also different: for example, the average $\mathrm{Mg}$ bioavailability of magnesium oxide, compared to magnesium phosphate, is around 20 vs. $45 \%$ [15]. 
Table 2. Mg content of mineral supplements. Adapted from [15].

\begin{tabular}{cc}
\hline Mg Source & Mg Content (g/100 g) \\
\hline Mg oxide & $50.5-52.0$ \\
\hline Mg hydroxide & $36.0-38.0$ \\
\hline Mg phosphate & $24.0-33.0$ \\
\hline Mg chloride & 12.0 \\
\hline Mg sulphate & 10.0 \\
\hline
\end{tabular}

The recommendations of the National Research Council (NRC) for different farm species are as follows: $400 \mathrm{mg} / \mathrm{kg} \mathrm{Mg}$ dry matter (DM) for pigs [16], $500 \mathrm{mg} / \mathrm{kg} \mathrm{Mg} \mathrm{DM} \mathrm{for}$ broilers, turkey poults and laying hens (with a food intake of $100 \mathrm{~g} /$ day) [17]. A different scenario exists for ruminant animals (beef and dairy cattle, sheep, and goat). Insufficient absorption or availability of $\mathrm{Mg}$ in ruminants leads to $\mathrm{Mg}$ deficiency which manifests in clinical signs such as tetany (grass tetany) or parturient paresis (milk fever). Intuitively, excessive $\mathrm{Mg}$ supplementation has also some detrimental effects. In farm animals, diarrhea is the most obvious effect of high intake of Mg. Very high dietary Mg intake (e.g., about seven times fold the minimum requirement for pigs) [18] can reduce feed consumption and weight gain.

However, combining quantities of $\mathrm{Mg}$ recommended in each species per $\mathrm{kg}$ of metabolic weight (body weight ${ }^{0.75}$; Table 3 ), it is evident that the quantities recommended for pig and poultry are higher than ruminants. These differences might depend from several factors that can be linked to the animals and their diets. Poultry and pigs are omnivorous species, with very fast growth rates that reach in modern breeds $100 \mathrm{~g}$ and $1 \mathrm{~kg} /$ day, respectively. These figures speak for themselves. Such growth performance needs a lot of energy and nutrients including minerals. Cow, considered as the reference ruminant's animal in the present work, is an adult herbivorous animal in which the $\mathrm{Mg}$ absorption and metabolism, starting from the rumen, is different and in which the main output is in milk. The lowest values reported for cow probably explain its sensitivity to the $\mathrm{Mg}$ deficiency especially at the onset of lactation (e.g., milk fever). By contrast, the recommended quantities in humans (see below) are enough to reach an adequate steady-state condition in typical adult male humans (maintenance).

Table 3. Recommended quantities of $\mathrm{Mg}$ (expressed per $\mathrm{kg}$ of metabolic body weight) in selected species.

\begin{tabular}{cccc}
\hline Species & Body Weight (BW) & Mg of Mg/kg of Metabolic BW * & \% (Relative to Humans) \\
\hline Human (adult) & $70 \mathrm{~kg}$ & 12.4 & 100 \\
Pig & $100 \mathrm{~kg}$ & 33.5 & 270.1 \\
Poultry & $3.5 \mathrm{~kg}$ & 19.6 & 158 \\
Cow & $600 \mathrm{~kg}$ & 0.25 & 2 \\
\hline
\end{tabular}

${ }^{*}$ Metabolic BW $=\mathrm{BW}^{0.75}$.

\section{Mg Supplementation in Pig Nutrition}

The minimum $\mathrm{Mg}$ requirement for pigs receiving a purified diet is $325 \mathrm{mg} / \mathrm{kg} \mathrm{DM}$ and, accordingly to NRC [16], $400 \mathrm{mg} / \mathrm{kg}$ DM are recommended. Higher supplementations have been reported for optimum growth and reproductive performance in pigs $(400-500 \mathrm{mg} / \mathrm{kg} \mathrm{DM})$. Thus, the dietary intake of $400 \mathrm{mg} / \mathrm{kg}$ is considered sufficient and $500-650 \mathrm{mg} / \mathrm{kg} \mathrm{Mg}$ is recommended for pigs. On the other hand, the demand for $\mathrm{Mg}$ increases proportionally to the protein content of the diet [15]. Deficiency symptoms in pigs include a strong response of the nervous system (hypersensitivity, anxiety, fear), muscle contractions and a drop in productivity (a slower growth rate because of loss of appetite). The kidney is the major site of $\mathrm{Mg}$ homeostasis and is able to excrete $\mathrm{Mg}$ at high dietary concentrations and reabsorb $\mathrm{Mg}$ with greater efficiency at low dietary concentrations. 
In terms of sources, $\mathrm{Mg}$ can be found in several feeds, such as green forage, animal derived feed, and mineral supplements. Feed ingredients like wheat bran, dried yeast, linseed meal, and cottonseed meal are good sources of $\mathrm{Mg}$. The average content $(\mathrm{g} / \mathrm{kg}$ $\mathrm{DM}$ ) of $\mathrm{Mg}$ in cereals, oil meals and fish meals is: $1.1-1.3 \mathrm{~g}, 3.0-5.8 \mathrm{~g}$, and 1.7-2.5 $\mathrm{g}$, respectively [15]. However, when $\mathrm{Mg}$ digestibility is considered, these figures must be reconsidered: in common pig feeds only 20 to $30 \%$ is digestible [18]. For this reason, supplements like $\mathrm{MgO}$ are commonly used in pig formulas. As in the other non-ruminant animals (pigs and poultry), $\mathrm{Mg}$ is absorbed primarily in the small intestine, at an efficiency of approximately $60 \%$, mostly via passive transport. In this site, potassium, calcium and ammonia are its antagonists [15].

\subsection{The Effects of Mg on Meat Quality}

Regarding pigs, a nutritional regime is one of the key environmental factors affecting fattening results, farm financial return and meat quality. Dietary Mg supplementation in pigs has generally been ineffective for increasing growth of fattening pigs (average daily gain), but has been observed to improve pork quality [18], specifically colour and drip loss [19].

Colour is one of the most important meat quality characteristics. It is a visual element that depends on the presence of pigments, the tissue composition, and texture of meat. There is a correlation between meat colour and the $\mathrm{pH}$ of muscles. Changes in meat colour are, in $50 \%$ of cases, determined by $\mathrm{pH}$ values measured $24 \mathrm{~h}$ post-harvest. Meat appearance is positively affected by nutritional factors, such as vitamin C, vitamin $\mathrm{E}$, selenium, and $\mathrm{Mg}$ content. In post-harvest processes in muscles, glycogen is converted into lactic acid and the $\mathrm{pH}$ of meat decreases, leading to the occurrence of Pale Soft Exudative (PSE) meat defects. The PSE is a condition that occurs usually during the conversion of muscle to meat. PSE has been documented mostly in pork carcasses, even though it is also reported in other species. The typical $\mathrm{pH}$ in pork would be 6.5-6.7 with a temperature of $37^{\circ} \mathrm{C}$ at $45 \mathrm{~min}$ post-mortem. However, in unusual carcasses, the $\mathrm{pH}$ may drop to 6.0 in the same time period. In this latter case, the combination of rapidly decreasing $\mathrm{pH}$ and high carcass temperature results in the denaturation of some of the contractile proteins, with consequent loss of water holding capacity (drip loss). Denatured proteins are not capable of holding or binding muscle water, as well as fully native proteins. More specifically, the length of the myosin filaments decreases by $8-10 \%$ during this process. PSE meat is usually of pale colour, wet in appearance, and very soft in texture, thus making PSE one of the major quality defects in meat industry [20]. This defect reduces consumer's acceptability, shelf life, and yield of meat, thus affecting profits tremendously. To cope with this problem, it has been shown that $\mathrm{Mg}$ inhibits stress-induced glycolysis, thus improving meat quality [21,22]. That's why the addition of $\mathrm{Mg}$ to finisher diets has been found to reduce the incidence of PSE meat from 15 to $50 \%$ of carcasses. Therefore, adding this mineral could decrease drip loss and improve meat colour from 3.6 to $6.6 \%$ with a short-term administration. Specifically, $\mathrm{Mg}$ improves colour stability and reduces drip loss.

$\mathrm{Mg}$ supplementation is a relatively easy method of improving pork quality [18]. Animal diets can be supplemented with organic (proteinate, aspartate) or inorganic (oxide, sulphate, chloride, phosphate) forms of Mg. A good solution to obtain this effect is to add $\mathrm{Mg}$ to drinking water: the administration of $600 \mathrm{mg}$ of $\mathrm{Mg}$ per litre of water, for two days before slaughter (short term), has been found to be also effective [23].

\section{2. $\mathrm{Mg}$ for Sows}

The reproductive performance of high producing sows has increased dramatically over the past decades, which may contribute to the changes in their nutritional requirements. It has been proven that $\mathrm{Mg}$ supplementation improves the conception rate of sows by $11-15 \%$ [10]. Moreover, its supplementation significantly reduces the weaning to oestrus interval in gilts and enhances the total number of born piglets, born alive, and weaned. This increase is particularly evident for sows fed with $150-300 \mathrm{mg} / \mathrm{kg}$ of supplemental Mg 
(basal diet contains $210 \mathrm{mg} / \mathrm{kg}$ of $\mathrm{Mg}$ ). The improvement of sows' performance may be related to a reduced incidence of constipation, which has been shown to negatively affect the reproductive performance of sows.

In addition, the increased levels of $\mathrm{Mg}$ in sows' lactation diet has a repercussion on its concentration in colostrum, as well as in the serum of piglets. This has been recently reported by Zang et al. [10], who evidenced that the increase in Mg content in sow's lactation diets can lead to the increase, not only of the concentration of $\mathrm{Mg}$ in colostrum, but also of the serum $\mathrm{Mg}$ concentration in suckling piglets. These results highlight the role of the maternal diet in defining piglets' nutritional status (e.g., their Mg status).

However, these effects observed in sows appeared to be age-related, which may be due to depleted body stores of minerals in high producing sows as they age [24]. Therefore, it is possible that, as the sows age, $\mathrm{Mg}$ stores in their body decline, increasing the reliance on the diet to provide it. In addition, dietary $\mathrm{Mg}$ supplementation positively affects pork quality by enhancing meat colour and reducing drip loss.

Mg supplementation also improves sows' fertility (e.g., conception rate) and helps during pregnancy in controlling constipation problems. Furthermore, the increase in dietary $\mathrm{Mg}$ in lactating sows leads to the increase in both $\mathrm{Mg}$ colostrum content and $\mathrm{Mg}$ serum content of suckling piglets (i.e., their $\mathrm{Mg}$ status).

\section{Mg Supplementation in Poultry Nutrition}

The minimum $\mathrm{Mg}$ requirement for broilers, turkey poults, and laying hens is around $500 \mathrm{mg} / \mathrm{kg}$ DM, accordingly to NRC [17]. Mg supplementation in poultry is affected by the growth rate and reproductive performance [6], but it is usually suggested after the third week of age, for preventing leg bones malformation. After this phase, $\mathrm{Mg}$ supplementation is recommended specially to prevent its deficiency. Indeed, $\mathrm{Mg}$ deficiency in avian species could lead to serious biochemical and symptomatic variations: for example, in young poultry (older than 3 weeks), it has been observed that it caused poor growth of body and feathering, decreased muscle tone, incoordination, squatting, fine palpable tremors, convulsive attacks, coma, and ultimately death [7]. In laying hens, the symptoms are different: reduced egg production, decreased feed consumption, nervous tremor, and seizures are the most reported deficiency signs. By contrast, adequate $\mathrm{Mg}$ supplementation in poultry exerts beneficial effects, increasing weight gain of broilers and meat quality, and egg production of laying hens. The influence of increased $\mathrm{Mg}$ levels fed to parent stock on progeny performance is another area of interest. Parent stock's breeders supplementation with $\mathrm{Mg}$ (up to $500 \mathrm{mg} / \mathrm{Mg} /$ day) positively affects egg quality and hatchability [4,6]. Recent results also showed that $\mathrm{MgO}$ supplementation improved FCR and skeletal integrity $[4,7,25]$ and exerted a positive effect on pullet skeletal development, body weight and onset of egg production [26].

\section{Interaction with $\mathrm{C}$ a and $\mathrm{P}$}

$\mathrm{Mg}$ metabolism is closely associated with $\mathrm{Ca}$ and P. These are two important minerals for laying hens that affect productive performance and eggshell quality. The use of $\mathrm{Ca}$ and $\mathrm{P}$ compounds appears to be determined largely by the relative proportions in which these elements and $\mathrm{Mg}$ are present in the ration. The commercial diet of chickens younger than 3 weeks of age should not be supplemented with $\mathrm{Mg}$, as this leads to leg bone malformation and development of perosis-like symptoms. An antagonistic relationship also seems to exist between $\mathrm{Ca}$ and $\mathrm{Mg}$ in relation to skeletal integrity and eggshell quality in laying hens. An increased dietary $\mathrm{Mg}$ supply in laying hens, although not affecting $\mathrm{Ca}$ retention, reduces eggshell $\mathrm{Ca}$ content and bone $\mathrm{Ca}$ content, whereas shell $\mathrm{Mg}$ content is increased [7]. The variety of mechanisms related to $\mathrm{Mg}$-Ca interaction demonstrates the need of close regulation of any variation in $\mathrm{Mg}$ level in poultry diets. Nutritionists today strive for optimisation of $\mathrm{P}$ content in poultry diets because of the high costs of P supplements, finiteness of phosphate rock supply and negative ecological impact of high P excretions. A supplementation with extra-nutritional levels of $\mathrm{Mg}$ to commercial 
poultry feed may disturb $\mathrm{P}$ as well as Ca availability, and thus negatively impacting bird performance and bone mineralization, especially in laying hens [27]. From another point of view, other dietary constituents can affect $\mathrm{Mg}$ bioavailability, retention and finally $\mathrm{Mg}$ status of poultry. Among these, the phytate effect is one of the most known: dietary phytate generally decreases $\mathrm{Mg}$ absorption in poultry through the formation of insoluble $\mathrm{Ca}-\mathrm{Mg}$-phytate complexes under the $\mathrm{pH}$ conditions of the small intestine. Use of phytase enzymes (common practice in poultry diets) might prevent this detrimental effect [28].

$\mathrm{Mg}$ is an essential element in poultry nutrition. Although most compound feeds for poultry contain $\mathrm{Mg}$ to an extent that makes $\mathrm{Mg}$ deficiency unlikely under practical conditions, other dietetic features of poultry formulas merit attention. Indeed, in specific poultry compound feeds (e.g., laying hens, breeders, specific $\mathrm{Ca}$ and $\mathrm{P}$ ratios, presence of phytate, etc.) $\mathrm{Mg}$ supplementation can be recommended for designing balanced diets aimed at achieving maximal performance.

\section{Mg Supplementation in Cow Nutrition}

In dairy and beef cows' diets, $\mathrm{Mg}$ is generally recommended at 1.2 to $3 \mathrm{~g} / \mathrm{kg}$ DM $[29,30]$. An adequate dietary supply of $\mathrm{Mg}$ supports animal's health and prevents deficient conditions. The most important deficient conditions are grass tetany and milk fever. Grass tetany is a clinical sign of hypomagnesaemia in cows, in which $\mathrm{Mg}$ level in cerebrospinal fluid decreases below a critical level $(<0.7 \mathrm{mmol} / \mathrm{L})$, following a decrease in blood plasma. This impairs the synaptic activity of neurons and causes symptoms such as excitement and muscular spasms (tetany). It is recognized that the incidence of grass tetany in cows is related to the fertilization of pastures with fertilizers containing $\mathrm{K}$, which impairs $\mathrm{Mg}$ absorption. Milk fever (or parturient paresis) is another pathological condition characterized by hypomagnesaemia and low plasma Ca concentrations $(<1.4 \mathrm{mmol} / \mathrm{L})$. Milk fever typically occurs around calving when there is a sudden increase in Ca losses through milk. Subclinical hypomagnesaemia reduces the ability of cows to mobilise calcium in response to hypocalcemia. In particular, $\mathrm{Mg}$ is required and involved in Ca absorption from the gut and Ca mobilization from bones, in order to maintain Ca homeostasis in plasma [4].

Apart from $\mathrm{Mg}$ deficient conditions, $\mathrm{Mg}$ supplementation is crucial to sustain ruminants' performance. $\mathrm{Mg}$ requirement of modern dairy cows has increased, partly due to increased use of nitrogen $(\mathrm{N})$ and potassium $(\mathrm{K})$ fertilizers, and partly due to an increase in cow genetic merit. All cows are to some extent deficient in $\mathrm{Mg}$ in late pregnancy and early lactation. High producing cows (typically producing more than $40 \mathrm{~kg}$ of milk per day) are more at risk of $\mathrm{Mg}$ deficiency.

Due to pasture and forage consumption by ruminants, $\mathrm{Mg}$ in soil is important in defining Mg availability for these animals. Mg content in soil differs between the various soil types and its availability to plants is influenced by several factors such as soil $\mathrm{pH}$, organic matter content and fertilization [31]. This latter is an important feature on which depends the availability of minerals, including Mg. It has been observed that fertilization of soil with $\mathrm{MgO}$ provided and increased $\mathrm{Mg}$ content in grass, but it was considered insufficient to prevent $\mathrm{Mg}$ deficiency. Instead of this approach, direct $\mathrm{Mg}$ supplementation in cows' diets is considered the best practice to prevent grass tetany and milk fever $[5,8,9]$.

\subsection{Dietary Interactions on $\mathrm{Mg}$ Absorption}

There are some dietary interactions between single components of feedstuffs, such as minerals, and $\mathrm{Mg}$ absorption. One of the most known in ruminants is a negative interaction between $\mathrm{K}$ intake and $\mathrm{Mg}$ absorption at ruminal level, as seen by the use of manure as fertilizer. The rumen is an important site of $\mathrm{Mg}$ absorption for cows [4]. Indeed, at low $\mathrm{K}$ level in ruminal epithelial cells, the apical membrane potential provides a driving force for Mg uptake by the cells, whereas at high ruminal $\mathrm{K}$ level there is a depolarization of the membrane potential, thereby causing a reduction in $\mathrm{Mg}$ uptake by cells. It can be assumed that ruminal $\mathrm{K}$ concentration is linked to apical membrane potential $[4,8,32]$. This phenomenon was clearly observed in sheep, in which an increase of $1 \mathrm{~g} / \mathrm{kg}$ DM in dietary 
K concentration decreased Mg absorption by 0.3\% [33] (Figure 1). Mg absorption occurs also in small intestine at duodenal level, although a minor absorption rate is observed also in the large intestine.

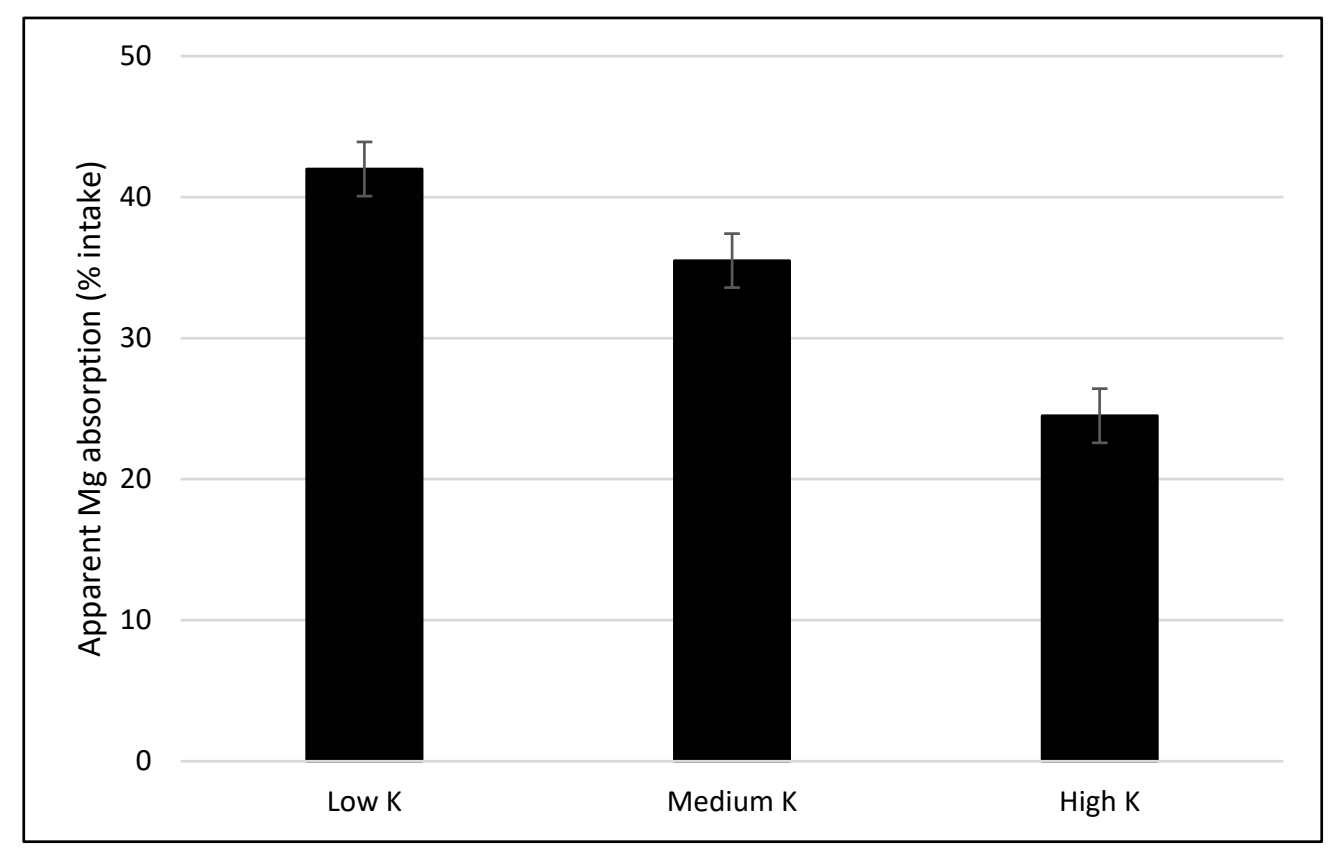

Figure 1. The effect of different dietary levels of $\mathrm{K}$ on apparent absorption of $\mathrm{Mg}$ (\% intake) in sheep. Levels of K are expressed as g/kg dry matter (DM). Low K: $15.7 \mathrm{~g} / \mathrm{kg}$ DM; medium K: $37.6 \mathrm{~g} / \mathrm{kg}$ DM; high K: 77.4 g/kg DM. Standard error mean = 1.92. Data from [33].

Furthermore, Na deficiency is also linked to lowered Mg absorption, because Na level decreases at the expense of $\mathrm{K}$ level, thereby resembling the condition of high $\mathrm{K}$ level that impairs Mg absorption. Finally, it has been observed that starch supplementation increases $\mathrm{Mg}$ absorption in rats and humans [34]. This effect has not been observed in cows yet, but the reason could be that the intake of high amounts of carbohydrates, such as starch, could cause a decrease in ruminal $\mathrm{pH}$, thereby raising $\mathrm{Mg}$ solubility and consequently its absorption.

\subsection{Prevention of $\mathrm{Mg}$ Deficiency}

The prevention of Mg deficiency must be performed both at short and long term, in order to prevent acute and chronic adverse conditions related to $\mathrm{Mg}$ deficiency. If there is a sudden need to avoid $\mathrm{Mg}$ deficiency, it is recommended to raise the dietary $\mathrm{Mg}$ content to adequate levels through the use of compound feeds. There are three main different forms of $\mathrm{Mg}$ that are used in ruminants' compound feed: $\mathrm{Mg}$ sulphate, $\mathrm{Mg}$ chloride, and $\mathrm{Mg}$ oxide. $\mathrm{Mg}$ sulphate is considered a good bioavailable source of $\mathrm{Mg}$ as well as $\mathrm{Mg}$ oxide, which is the most common source of $\mathrm{Mg}$ used to prevent milk fever. Both $\mathrm{Mg}$ sulphate and $\mathrm{Mg}$ chloride can contribute to decreasing the so-called dietary cation-anion difference (DCAD), commonly calculated as $\left(\left(\mathrm{Na}^{+}+\mathrm{K}^{+}\right)-\mathrm{Cl}^{-}+\mathrm{S}^{2-}\right)$ and expressed in milliequivalents $(\mathrm{mEq})$. When $\mathrm{Mg}$ sulphate or $\mathrm{Mg}$ chloride are used as a source of supplemental Mg, their accompanying anions can reduce that balance, even if in terms of bioavailability $\mathrm{Mg}$ chloride should be intuitively preferred to both manipulate DCAD and prevent milk fever in dairy cows [8].

$\mathrm{Mg}$ supplementation in ruminants' feeding is important both to sustain the metabolic activity of the enzymes that use $\mathrm{Mg}$ as cofactor and to prevent hypomagnesaemic clinical conditions such as grass tetany and milk fever. $\mathrm{Mg}$ intake and absorption in small intestine are strictly correlated and are subject to the influence of several factors, of which $\mathrm{K}$ level is one of the most important: a high $\mathrm{K}$ intake inhibits $\mathrm{Mg}$ absorption, thus increasing the 
risk of $\mathrm{Mg}$ deficiency. The K-induced inhibitory mechanism can be counteracted using supplemental dietary $\mathrm{Mg}$ to raise $\mathrm{Mg}$ level at short and long term.

\section{Magnesium in Human Nutrition}

\subsection{Animal-Derived Food as Source of Dietary $M g$}

$\mathrm{Mg}$ supplementation in farm animals' diets ensures an adequate $\mathrm{Mg}$ content in animal derived foods and consequently the $\mathrm{Mg}$ intake from these foods for humans. Whilst in the typical European diet cereals or cereal-derived foods are the largest source of $\mathrm{Mg}$ intake, animal-derived foods also make an important contribution. Typically, the recommended dietary intake of $\mathrm{Mg}$ for humans is around $300-400 \mathrm{mg} /$ day. However, the reference values vary in relation to age and sex. For example, the recommended dietary intake for adult males is $350 \mathrm{mg}$ /day, whereas for adult females is $300 \mathrm{mg} /$ day [35]. Table 4 summarizes the contribution that animal-derived foods make to $\mathrm{Mg}$ intake in a selection of studies in several European countries. The data relate primarily to adults and some are relatively old but broadly indicate that meat, milk and dairy products make the largest contribution, with some notable differences between countries. The contributions seen in these studies contrast considerably with the values from the Mediterranean Healthy Eating, Ageing and Lifestyle (MEAL) study in Sicily which reported contributions of only 7, 4, 3 and $0 \%$ from milk and dairy products, fish, meat, and eggs, respectively [36]. In addition, the data in Table 4 mask the substantial variation in the supply of $\mathrm{Mg}$ that age of populations can make. For example, in the recent UK National Diet and Nutrition Survey (NDNS), milk and dairy products provide 25,15 , and $13 \%$ of $\mathrm{Mg}$ intake of children aged 1.5-3 and 4-10 years and subjects aged $\geq 75$ years, respectively, compared with $9 \%$ in adults aged 19-64 years [37].

Table 4. Contribution of animal-derived foods to $\mathrm{Mg}$ intake by adults.

\begin{tabular}{|c|c|c|c|c|c|c|c|}
\hline \multirow[b]{2}{*}{ Country } & \multirow[b]{2}{*}{ Study } & \multirow[b]{2}{*}{ Gender } & \multicolumn{4}{|c|}{ Contribution to Mg Intake (\%): } & \multirow[b]{2}{*}{ Reference } \\
\hline & & & $\begin{array}{l}\text { Milk and Dairy } \\
\text { Products }\end{array}$ & Meat and Products & Eggs & Fish and Products & \\
\hline Italy & Total-diet ${ }^{1}$ & Mixed & 11 & 13 & $\mathrm{NG}^{2}$ & 5 & [38] \\
\hline Italy & $\begin{array}{l}\text { INRAN-SCAI, } \\
\text { 2005-06 }\end{array}$ & Mixed & 12 & 10 & 1 & 5 & [39] \\
\hline Italy & EPIC & Men & 6.8 & 10.0 & 0.1 & 2.4 & [40] \\
\hline Italy & EPIC & Women & 9.0 & 9.3 & 0.2 & 2.3 & [40] \\
\hline United Kingdom & EPIC & Men & 13.2 & 9.2 & 0.2 & 2.7 & [40] \\
\hline United Kingdom & EPIC & Women & 14.1 & 7.9 & 0.2 & 2.7 & [40] \\
\hline United Kingdom & NDNS & Mixed 19-64 years & 9 & 15 & 1 & 3 & [37] \\
\hline Greece & EPIC & Men & 8.4 & 6.1 & 0.1 & 5.0 & [40] \\
\hline Germany & EPIC & Men & 6.2 & 12.1 & 0.1 & 1.5 & [40] \\
\hline The Netherlands & EPIC & Men & 10.2 & 11.8 & 0.2 & 1.2 & [40] \\
\hline
\end{tabular}

${ }^{1}$ Based on food purchases so will include children ${ }^{2}$ No value given.

It is noteworthy that milk makes a greater contribution to $\mathrm{Mg}$ intake in very young and elderly subjects who are likely to be at greater risk of sub-optimal nutrition and will benefit from the high bioavailability of $\mathrm{Mg}$ in milk. A number of studies have shown that lactose in dairy products can enhance intestinal absorption of $\mathrm{Mg}$ in infants [41] and animal models [35]. This enhancement of $\mathrm{Mg}$ absorption has been attributed to the lowering of $\mathrm{pH}$ in the ileum by lactose fermentation which reduces the synthesis of insoluble CaMg-phosphate complexes thus increasing absorption of $\mathrm{Mg}$ in the ileum. The benefits of lactose in this regard will of course be lost to subjects that are lactose intolerant and thus choose lactose-free dairy products. Table 5 summarizes the content of Mg in several animal-derived foods. 
Table 5. Distribution of $\mathrm{Mg}$ content ( $\mathrm{mg} / \mathrm{kg}$ of fresh $\mathrm{wt}$ ) in selected foods of animal origin. Adapted from [35,42-44].

\begin{tabular}{cccc}
\hline Animal-Derived Food & Mg & Animal-Derived Food & Mg \\
\hline Chicken (range) & $140-210$ & Cow's Milk (range) & $86-100$ \\
\hline Breast & 210 & Whole milk (3.25\% fat) & $98-110$ \\
Drumstick & 196 & Reduced Fat milk (2\% fat) & $98-111$ \\
Chicken meat products & $135-142$ & Low fat milk (1\% fat) & $98-112$ \\
Pork (range) & $195-290$ & Skim milk & $98-113$ \\
Loin & 207 & Goat milk & 139 \\
Neck & 212 & Sheep milk & 180 \\
Hind leg & 237 & Dairy products (range) & $20-425$ \\
Shoulder & 195 & Cream & 60 \\
Sausage & $117-289$ & Butter & 20 \\
& & Cheese & $130-425$ \\
\hline
\end{tabular}

Whilst the data in Table 5 consistently show the importance of milk and meat as dietary sources of $\mathrm{Mg}$, they do not reflect differences in $\mathrm{Mg}$ intake with some recent trends giving rise for concern. For example, in the recent UK NDNS, Roberts et al. [37] report that 50,14 , and $27 \%$ of adolescent females (11-18 years), adult females (19-64 years), and elderly females ( $\geq 75$ years), respectively, have $\mathrm{Mg}$ intakes below the Lower Reference Nutrient Intake (LRNI). Equivalent values for males $(27,11$, and $22 \%$ ) are less extreme but are also concerning. The LRNI is that which is assumed to satisfy the nutrient requirements of the bottom $2.5 \%$ of the population so intakes considerably lower than this reflect how serious this situation is. It is noteworthy that in the UK milk and red meat consumption, especially by young females, has reduced over recent decades and this will have contributed to the substantially suboptimal intake of $\mathrm{Mg}$ and some other nutrients currently seen [45]. It is also interesting that the European Food Safety Authority (EFSA) [13] has recommended what it describes as 'adequate intakes' of $\mathrm{Mg}$ which for children aged 3 to 15 years are substantially higher than the UK Reference Nutrient Intakes for that age group.

The role of $\mathrm{Mg}$ as a cofactor in many body enzyme systems has been known for some time. Many of these involve adenosine triphosphate (ATP), which is involved in a wide range of biochemical pathways including intermediary metabolism related to the synthetic pathways for carbohydrates, lipids and proteins. About $60 \%$ of body $\mathrm{Mg}$ is in bone [46] and some $25 \%$ is in muscle mitochondria [47] and it is now becoming clear that its role in the musculoskeletal system is vital in relation to diet-related chronic diseases [48].

\section{2. $\mathrm{Mg}$ and Bone Health}

Whilst it has been recognised for some considerable time that adequate intakes of protein and $\mathrm{Ca}$ together with an optimum vitamin D status are important prerequisites for bone development it is now becoming clear that $\mathrm{Mg}$ also has a crucial role. Research with children aged 4-8 years reported that Ca intake, when not very sub-optimal, was not substantially linked to bone mineral status, whereas $\mathrm{Mg}$ intake, and particularly the amount absorbed, were important predictors of bone mineral density and bone mineral content [49]. The authors highlight that this work provides good evidence that $\mathrm{Mg}$ should be more considered as an important nutrient in relation to bone development. In addition, more recently the Japanese Kuopio Ischemic Heart Disease prospective study has shown that low serum Mg concentrations in men aged 42-61 years were associated with increased bone fracture risk [50]. To what extent these findings are relevant to other populations is uncertain at present, but ensuring that adequate $\mathrm{Mg}$ intake is clearly and especially important during the phase of rapid bone growth in late childhood/ and early adolescence. $\mathrm{Mg}$ is now also known to have a considerable interaction with vitamin $\mathrm{D}$ being an essential cofactor for vitamin D synthesis and its subsequent activation, which in turn can increase intestinal absorption of $\mathrm{Mg}$ [51]. This further highlights the importance of $\mathrm{Mg}$ in bone health. Given the co-existence of sub-optimal vitamin D status, the substantially sub- 
optimal Mg intakes in UK female adolescents noted above is a matter of substantial concern.

There is also increasing evidence of a benefit of $\mathrm{Mg}$ for bone health in later life. Erem et al. [52] reviewed studies which showed that the risk of osteoporosis in older subjects can be a consequence of low $\mathrm{Mg}$ intake. This can lead to excess Ca release from the bones with the resultant increased excretion leading to increased bone fragility and hence a higher risk of bone fractures. In addition, high intakes of Ca can lead to lower retention of $\mathrm{Mg}$ and it has been proposed that the optimal dietary ratio of $\mathrm{Ca}: \mathrm{Mg}$ is between 2.0:1.0 and 2.8:1.0 [52] but they highlight that in a lot of current US diets the ratio above 3.0:1.0.

There is clearly an urgent need for further research on the interaction of $\mathrm{Mg}$ with $\mathrm{Ca}$ and vitamin $\mathrm{D}$ in relation to bone development in the young and bone strength in the elderly. It is well known that milk and dairy products are excellent sources of $\mathrm{Ca}$ and, as noted above, also an important source of $\mathrm{Mg}$ for the young and elderly, as well as being an excellent vehicle for vitamin $\mathrm{D}$ fortification.

\section{3. $\mathrm{Mg}$ and Sarcopenia}

Sarcopenia is a condition mainly associated with chronic loss of muscle mass and muscle function with advancing age [53]. It also predicts functional decline, hospitalization, and living in community dwelling for the elderly. It is therefore a condition of increasing importance in the elderly (although it can occur in middle age) with an increasing prevalence associated with the increasing age of many populations worldwide. The condition can have consequences additional to simple muscle loss, as for example, it reduces the protection of the bone with increased risk of bone breakage in a fall which can have an immense effect on mobility, disability and general quality of life. A less well appreciated outcome of reduced muscle mass and the associated reduced mobility is the increased risk of metabolic diseases, particularly type 2 diabetes [54]. Since skeletal muscles are the major site of glucose uptake and clearance from the circulation, reduction in muscle mass can adversely affect glycemic control [55].

As with the influence of $\mathrm{Mg}$ intake on bone mineralization noted earlier, there is also increasing evidence of an association between $\mathrm{Mg}$ and preservation and functionality of skeletal muscle. Dominguez et al. [56] used baseline data from the prospective study named "Invecchiare in Chianti" (InCHIANTI, Aging in the Chianti area of Tuscany) on risk factors for late-life disability. They selected 1138 men and women (aged $66.7 \pm 15.2$ y) with full data on muscle performance and blood Mg. After adjustments for key confounders (age, sex, etc.) serum Mg concentrations were significantly and positively associated with muscle performance as assessed by measures including grip strength $(p=0.0002)$, lower leg muscle power $(p=0.001)$, and knee extension torque $(p<0.0001)$. More recently Welch et al. [57] studied the cross-sectional associations between $\mathrm{Mg}$ intake and skeletal muscle mass (expressed as fat-free mass (FFM) as a percentage of body weight (FFM\%)) and grip strength in 56,575 males and females aged 39-72 years from the UK Biobank cohort. They found positive associations between quintiles of $\mathrm{Mg}$ intake and grip strength ( $p$ trend $<0.001$ ) and FFM $\%$ ( $p$ trend $<0.001$ ). They reported that the relationship with grip strength was stronger for men $\geq 60$ years of age than in younger men, although the opposite was the case for women. The authors indicated that this study was the largest population to date used to study the association between $\mathrm{Mg}$ intake and direct functionality measures of skeletal muscle.

Zhang et al. [58] reviewed the evidence from animal and human studies as to whether $\mathrm{Mg}$ can enhance performance during exercise. They concluded that animal studies showed that $\mathrm{Mg}$ might improve exercise performance, possibly by increasing glucose availability to the brain and muscles whilst lowering and delaying lactate accumulation in the muscles. They found that human studies had primarily examined physiological effects such as blood pressure, heart rate and maximal oxygen uptake $\left(\mathrm{VO}_{2}\right.$ max) rather than direct muscle performance but they did report evidence that $\mathrm{Mg}$ supplementation might enhance some performance parameters in both aerobic and anaerobic exercise regimes. Despite blood 
only containing about $1 \%$ of total body $\mathrm{Mg}$, serum $\mathrm{Mg}$ concentration has been used as a measure of Mg status in most studies. Recently however, Cameron et al. [59] showed that the measurement of intramuscular ionised $\mathrm{Mg}$ using phosphorus magnetic resonance spectroscopy ( ${ }^{31}$ PMRS) was positively associated with knee-extension strength $(p<0.001$ in women; $p=0.003$ in men), while total serum $\mathrm{Mg}$ was not associated with muscle strength $(p=0.27)$. The authors propose that intramuscular ionised $\mathrm{Mg}$ by ${ }^{31} \mathrm{PMRS}$ is a superior measure of $\mathrm{Mg}$ status than total serum $\mathrm{Mg}$, perhaps particularly when muscle weakness of an uncertain cause is found.

Clearly more work on the increasingly important relationship between $\mathrm{Mg}$ and muscle function is needed. Given the substantially sub-optimal $\mathrm{Mg}$ intakes in elderly populations such as in the UK [37] and the US [52], and the increasing prevalence of sarcopenia, this work is now urgent.

\section{4. $\mathrm{Mg}$ and Cancer Risk}

Although this area of work is relatively new there is an increasing interest in the possible association between $\mathrm{Mg}$ status and cancer risk. The recent case-control study of Huang et al. [60] explored the effect of dietary $\mathrm{Mg}$ intake on breast cancer risk directly and indirectly via the effect of $\mathrm{Mg}$ on the inflammatory markers C-reactive protein (CRP) and interleukin-6 (IL-6). Multivariable logistic regression was used to assess the odds ratio (OR) and 95\% confidence interval (95\% CI), together with path analysis to explore mediating effects. The results showed that a higher $\mathrm{Mg}$ intake $(\geq 280 \mathrm{mg} / \mathrm{d})$ was associated with a significantly lower risk of breast cancer (OR 0.80, 95\% CI 0.65, 0.99) than intakes $<280 \mathrm{mg} /$ day and there was an overall dose-response between $\mathrm{Mg}$ intake and breast cancer risk (Figure 2). Additionally, circulating CRP concentration was positively associated with the risk of breast cancer (OR 1.43, 95\% CI 1.02, 2.01). IL-6 showed no association with breast cancer risk but the path analysis identified that dietary $\mathrm{Mg}$ influenced breast cancer risk directly and indirectly by its lowering effect on CRP. As the authors noted, this study was the first of its kind but had weaknesses including the well-recognised limitations of case-control studies plus the fact that the measurement of the inflammatory markers was only made in relatively small number of subjects (322 cases and controls). Nevertheless, this study clearly supports the objective of increasing $\mathrm{Mg}$ intake including some populations noted earlier with substantial sub-optimal Mg intakes.

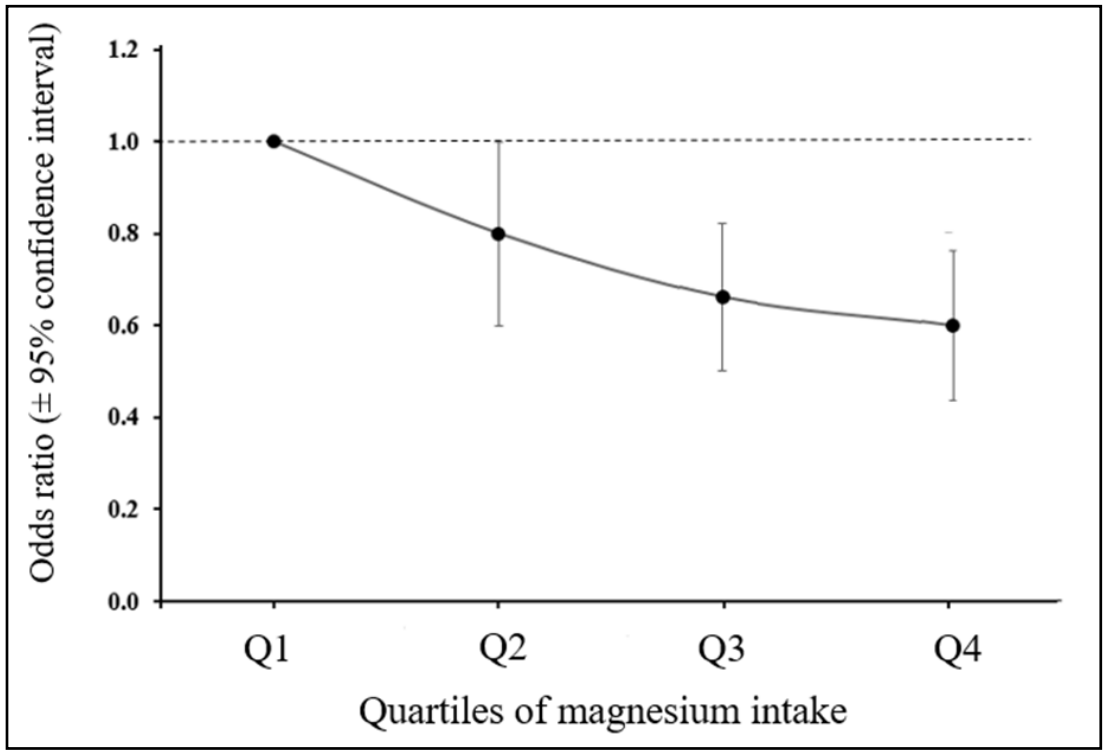

Figure 2. Dose-response association between $\mathrm{Mg}$ intake and risk of breast cancer in Chinese women. Derived from [60]. 
There is increasing evidence of an inverse association between vitamin $\mathrm{D}$ status (circulating 25(OH)D3) and mortality in colo-rectal cancer (CRC) patients and the metaanalysis of Maalmi et al. [61] involving 11 studies and 7718 CRC patients showed that those with the highest vitamin D status had significantly lower risk of all-cause mortality with a hazard ratio (HR) of 0.68 (95\% CI: 0.55, 0.85) and CRC cause mortality (HR 0.67, 95\% CI $0.57,0.78)$ than those with the lowest vitamin D status. As noted earlier, $\mathrm{Mg}$ is heavily involved in biochemical pathways for vitamin D synthesis and the conversion of 25(OH)D3 to the active $1,25(\mathrm{OH})_{2} \mathrm{D} 3$ form of vitamin D. The study of Wesselink et al. [62] with 1169 newly diagnosed patients examined the associations between circulating 25(OH)D3 concentrations, $\mathrm{Mg}$ or Ca dietary intake (including supplements) and recurrence rate and all-cause mortality. Overall, the study concluded that having an adequate vitamin D status together with an adequate $\mathrm{Mg}$ intake is essential for reducing the risk of mortality in CRC patients although the wide applicability and exact mechanisms are not known and should be investigated.

\section{Conclusions}

$\mathrm{Mg}$ is required in animal nutrition because of its major role in cellular metabolism and bone development and further to avoid adverse health conditions that impair animals' health and consequently their productivity. Usually, $\mathrm{Mg}$ minimum requirements are met only using common feed ingredients. However, the dramatic increase in productivity of high producing farm animals over the past decades has led to new challenges in nutritional requirements to support higher animal performance. For this reason, Mg supplementation in animal nutrition above the minimum requirements has been regarded as a best practice to face with higher performance, mainly in terms of fertility and product quality. $\mathrm{Mg}$ supplementation is essential also because it ensures an adequate Mg content in animalsource food. To summarize, $\mathrm{Mg}$ supplementation exerts beneficial effects in high producing farm animals in terms of productive and reproductive performances and is essential for their health and wellbeing.

In human nutrition $\mathrm{Mg}$ is also essential. It is a cofactor in more than 300 enzyme systems which regulate diverse biochemical reactions in the body, including protein synthesis, muscle and nerve transmission, neuromuscular conduction, signal transduction, blood glucose control, and blood pressure regulation. In light of this, the impact of sub-optimal Mg intake by humans can be substantial as there is increasing evidence of its key role in bone development, muscle function and an association with some health risk. In this respect dietary intake and source become also important. It is clear that for many populations the animal-derived foods, and notably meat, milk and dairy products are important dietary sources of $\mathrm{Mg}$ [35]. This also seems to be particularly important in age groups which have substantial nutrient insecurity such as adolescents and the elderly. It is also becoming increasingly clear that $\mathrm{Mg}$ and vitamin $\mathrm{D}$ have an interdependence and are involved in the aetiology of several chronic diseases which have an increasing prevalence. Whilst much needs to be known about the association of $\mathrm{Mg}$ with risk of chronic diseases, a concerted effort should be made by public health bodies to ensure $\mathrm{Mg}$ intake and vitamin D status are satisfactory.

Overall, the recommendation for both animals and humans is the same, do what is necessary to ensure an adequate dietary supply of $\mathrm{Mg}$.

Author Contributions: Conceptualization and literature review, L.P., M.M., and I.G.; writingoriginal draft preparation, L.P., M.M., and I.G.; writing-review and editing, L.F., M.T., and R.C. All authors have read and agreed to the published version of the manuscript.

Funding: This research received no external funding.

Institutional Review Board Statement: Not applicable.

Informed Consent Statement: Not applicable.

Data Availability Statement: Data sharing is not applicable to this article. 
Acknowledgments: The authors acknowledge support from the University of Milan through the APC initiative. Moreover, this work was developed as part of the PhD program in Nutrition Sciences, University of Milan.

Conflicts of Interest: The authors declare no conflict of interest.

\section{References}

1. Maguire, M.E.; Cowan, J.A. Magnesium chemistry and biochemistry. Biometals 2002, 15, 203-210. [CrossRef] [PubMed]

2. Jahnen-Dechent, W.; Kettelerm, M. Magnesium basics. Clin. Kidney J. 2012, 5, i3-i14. [CrossRef]

3. Picone, G.; Cappadone, C.; Farruggia, G.; Malucelli, E.; Iotti, S. The assessment of intracellular magnesium: Different strategies to answer different questions. Magnes. Res. 2020, 33, 1-11. [CrossRef]

4. Suttle, N. Mineral Nutrition of Livestock, 4th ed.; CABI: Cambridge, UK, 2010.

5. Martens, H.; Leonhard-Marek, S.; Röntgen, M.; Stumpff, F. Magnesium homeostasis in cattle: Absorption and excretion. Nutr. Res. Rev. 2018, 25, 1-17. [CrossRef] [PubMed]

6. Gaál, K.K.; Sáfár, O.; Gulyás, L.; Stadler, P. Magnesium in animal nutrition. J. Am. Coll. Nutr. 2004, 23, 754S-757S. [CrossRef] [PubMed]

7. Shastak, Y.; Rodehutcord, M. A review of the role of magnesium in poultry nutrition. Worlds Poult. Sci. J. 2015, 71, 125-137. [CrossRef]

8. Schonewille, J.T. Magnesium in dairy cow nutrition: An overview. Plant Soil 2013, 368, 167-178. [CrossRef]

9. Elliott, M. Grass tetany in cattle-Treatment and prevention. Primefacts NSW DPI 2009, 421, 1-4.

10. Zang, J.; Chen, J.; Tian, J.; Wang, A.; Liu, H.; Hu, S.; Che, X.; Ma, Y.; Wang, J.; Wang, C.; et al. Effects of magnesium on the performance of sows and their piglets. J. Anim. Sci. Biotechnol. 2014, 5, 39-46. [CrossRef]

11. Costello, M. Record Animal Protein Production Forecast out to 2020. Available online: https://research.rabobank.com/far/en/ sectors/animal-protein/record-animal-protein-production-forecast-2020.html (accessed on 16 September 2020).

12. Zulauf, C.; Rettig, N. Comparing Current and 1970 Farm Prosperity: U.S. Livestock Production. Available online: https: / / farmdocdaily.illinois.edu/2013/06/comparing-current-1970-farm-prosperity-livestock.html (accessed on 16 September 2020).

13. EFSA. NDA Panel (EFSA Panel on Dietetic Products, Nutrition and Allergies). Scientific opinion on dietary reference values for magnesium. EFSA J. 2015, 13, 1-63.

14. European Commission. Animal Feed. Available online: https://ec.europa.eu/food/safety/animal-feed_en (accessed on 16 September 2020).

15. Lipinski, K.; Stasiewicz, M.; Purwin, C.; Żuk-Gołaszewska, K. Effects of magnesium on pork quality. J. Elem. 2011, 16, 325-337. [CrossRef]

16. National Research Council (NRC). Nutrient Requirements of Swine, 10th ed.; National Academy Press: Washington, DC, USA, 1998.

17. National Research Council (NRC). Nutrient Requirements of Poultry, 9th ed.; National Academy Press: Washington, DC, USA, 1994.

18. van Heugten, E. Magnesium in Pig Nutrition. Available online: https://www.pig333.com/articles/magnesium-in-pig-nutrition_ 580 (accessed on 6 October 2020).

19. Apple, J.K.; Maxwell, C.V.; de Rodas, B.; Watson, H.B.; Johnson, Z.B. Effect of magnesium mica on performance and carcass quality of growing-finishing swine. J. Anim. Sci. 2000, 78, 2135-2143. [CrossRef]

20. Feiner, G. (Ed.) Definitions of terms used in meat science and technology. In Meat Products Handbook, Practical Science and Technology; Woodhead Publishing Series in Food Science, Technology; Woodhead Publishing: Cambridge, UK, 2006 ; pp. 46-71.

21. D'Souza, D.N.; Warner, R.D.; Dunshea, F.R.; Leury, B.J. Comparison of different dietary magnesium supplements on pork quality. Meat Sci. 1999, 51, 221-225. [CrossRef]

22. D'Souza, D.N.; Warner, R.D.; Leury, B.J.; Dunshea, F.R. The influence of dietary magnesium supplement type and supplementation dose and duration, on pork quality and the incidence of PSE pork. Aust. J. Agric. Res. 2000, 51, 185-189. [CrossRef]

23. Frederick, B.R.; van Heugten, E.; See, M.T. Timing of magnesium supplementation administered through drinking water to improve fresh and stored pork quality. J. Anim. Sci. 2004, 82, 1454-1460. [CrossRef] [PubMed]

24. Mahan, D.C.; Newton, E.A. Effect of initial breeding weight on macro- and micromineral composition over a three-parity period using a high-producing sow genotype. J. Anim. Sci. 1995, 73, 151-158. [CrossRef]

25. Pierson, E.E. Improve Broiler, Layer Bone Strength with Magnesium Oxide. Available online: https://www.wattagnet.com/ articles/31323-improve-broiler-layer-bone-strength-with-magnesium-oxide (accessed on 12 October 2020).

26. Lilburn, M.S.; Pierson, E.E.; Robison, C.I.; Karcher, D. Supplemental Magnesium in Diets for Growing Pullets and Hens: Growth, Skeletal Development, and Egg Production. J. Appl. Poultry Res. 2019, 28, 1202-1209. [CrossRef]

27. Li, P.; Wang, R.; Jiao, H.; Wang, X.; Zhao, J.; Lin, H. Effects of Dietary Phosphorus Level on the Expression of Calcium and Phosphorus Transporters in Laying Hens. Front. Physiol. 2018, 9, 627-638. [CrossRef]

28. Humer, E.; Schwarz, C.; Schedle, K. Phytate in pig and poultry nutrition. J. Anim. Physiol. Anim. Nutr. 2015, 99, 605-625. [CrossRef]

29. National Research Council (NRC). Nutrient Requirements of Beef Cattle, 8th ed.; National Academy Press: Washington, DC, USA, 1996.

30. National Research Council (NRC). Nutrient Requirements of Dairy Cattle, 7th ed.; National Academy Press: Washington, DC, USA, 2001. 
31. Gransee, A.; Führs, H. Magnesium mobility in soils as a challenge for soil and plant analysis, magnesium fertilization and root uptake under adverse growth conditions. Plant Soil 2013, 368, 5-21. [CrossRef]

32. Martens, H.; Schweigel, M. Pathophysiology of grass tetany and other hypomagnesemias. Implications for clinical management. Vet. Clin. N. Am. Food Anim. Pract. 2000, 16, 339-368. [CrossRef]

33. Jittakhot, S.; Schonewille, J.T.; Wouterse, H.S.; Yuangklang, C.; Beynen, A.C. The relationships between potassium intakes, transmural potential difference of the rumen epithelium and magnesium absorption in wethers. Br. J. Nutr. 2004, 91, 183-189. [CrossRef]

34. Schuchardt, J.P.; Hahn, A. Intestinal Absorption and Factors Influencing Bioavailability of Magnesium-An Update. Curr. Nutr. Food Sci. 2017, 13, 260-278. [CrossRef]

35. Cazzola, R.; Della Porta, M.; Manoni, M.; Iotti, S.; Pinotti, L.; Maier, J.A. Going to the roots of reduced magnesium dietary intake: A tradeoff between climate changes and sources. Helyion 2020, 6, e05390. [CrossRef]

36. Castiglione, D.; Platania, A.; Conti, A.; Falla, M.; D’Urso, M.; Marranzano, M. Dietary micronutrient and mineral intake in the Mediterranean Healthy Eating, Ageing, and Lifestyle (MEAL) Study. Antioxidants 2018, 7, 79. [CrossRef]

37. Roberts, C.; Steer, T.; Maplethorpe, N.; Cox, L.; Meadows, S.; Nicholson, S.; Page, P.; Swan, G. National Diet and Nutrition Survey. Results from Years 7-8 (Combined) of the Rolling Programme (2014/15 to 2015/16); Public Health England: London, UK, 2018.

38. Lombardi-Boccia, G.; Aguzzi, A.; Cappelloni, M.; Di Lullo, G.; Lucarini, M. Total diet study: Dietary intakes of macro elements and trace elements in Italy. Br. J. Nutr. 2003, 90, 1117-1121. [CrossRef]

39. Sette, S.; Le Done, C.; Piccinelli, R.; Mistura, L.; Ferrari, M.; Leclerq, C.; On Behalf of the INRAN-SCAI 2005-06 Study Group. The third National Food Consumption Survey, INRAN-SCAI 2005-06: Major dietary sources of nutrients in Italy. Int. J. Food Sci. 2013, 64, 1014-1021. [CrossRef]

40. Welch, A.A.; Fransen, H.; Jenab, M.; Boutron-Ruault, M.C.; Tumino, R.; Agnoli, C.; Ericson, U.; Johansson, I.; Ferrari, P.; Engeset, D.; et al. Variation in intakes of calcium, phosphorus, magnesium, iron and potassium in 10 countries in the European Prospective Investigation into Cancer and Nutrition study. Eur. J. Clin. Nutr. 2009, 63, S101-S121. [CrossRef] [PubMed]

41. Ziegler, E.E.; Fomon, S.J. Lactose enhances mineral absorption in infancy. J. Pediatr. Gastr. Nutr. 1983, 2, 288-294. [CrossRef]

42. Jodral-Segado, A.M.; Navarro-Alarcon, M.; de la Serrana, H.L.G.; Lopez-Martínez, C.M. Magnesium and calcium contents in foods from SE Spain: Influencing factors and estimation of daily dietary intakes. Sci. Total Environ. 2003, 312, 47-58. [CrossRef]

43. Oh, H.E.; Deeth, H.C. Magnesium in milk. Int. Dairy J. 2017, 71, 89-97. [CrossRef]

44. Djinovic-Stojanovic, J.M.; Nikolic, D.M.; Vranic, D.V.; Babic, J.A.; Milijasevic, M.P.; Pezo, L.L.; Jankovic, S.D. Zinc and magnesium in different types of meat and meat products from the Serbian market. J. Food Compos. Anal. 2017, 59, 50-54. [CrossRef]

45. Givens, D.I. Review: Dairy foods, red meat and processed meat in the diet: Implications for health at key life stages. Animal 2018, 12, 1709-1721. [CrossRef] [PubMed]

46. Musso, C.G. Magnesium metabolism in health and disease. Int. Urol. Nephrol. 2009, 41, 357-362. [CrossRef] [PubMed]

47. Wolf, F.I.; Trapani, V. Cell (patho)physiology of magnesium. Clin. Sci. 2008, 114, 27-35. [CrossRef] [PubMed]

48. Piuri, G.; Zocchi, M.; Della Porta, M.; Ficara, V.; Manoni, M.; Zuccotti, G.V.; Pinotti, L.; Maier, J.A.; Cazzola, R. Magnesium in obesity, metabolic syndrome and type 2 diabetes. Nutrients 2021, 13, 320. [CrossRef] [PubMed]

49. Abrams, S.A.; Chen, Z.; Hawthorne, K.M. Magnesium metabolism in 4-year-old to 8-year-old children. J. Bone Miner. Res. 2014, 29, 118-122. [CrossRef] [PubMed]

50. Kunutsor, S.K.; Whitehouse, M.R.; Blom, A.W.; Laukkanen, J.A. Low serum magnesium levels are associated with increased risk of fractures: A long-term prospective cohort study. Eur. J. Epidemiol. 2017, 32, 593-603. [CrossRef] [PubMed]

51. Uwitonze, A.M.; Razzaque, M.S. Role of magnesium in vitamin D activation and function. J. Am. Osteopath. Assoc. 2018, 118, 181-189. [CrossRef] [PubMed]

52. Erem, S.; Atfi, A.; Razzaque, M.S. Anabolic effects of vitamin D and magnesium in aging bone. J. Steroid Biochem. Mol. Biol. 2019, 193, 105400. [CrossRef] [PubMed]

53. Cruz-Jentoft, A.J.; Bahat, G.; Bauer, J.; Boirie, Y.; Bruyère, O.; Cederholm, T.; Cooper, C.; Landi, F.; Rolland, Y.; Sayer, A.A.; et al. Writing Group for the European Working Group on Sarcopenia in Older People 2 (EWGSOP2), and the Extended Group for EWGSOP2. Sarcopenia: Revised European consensus on definition and diagnosis. Age Ageing 2019, 48, 16-31. [CrossRef] [PubMed]

54. Hunter, G.R.; Singh, H.; Carter, S.J.; Bryan, D.R.; Fisher, G. Sarcopenia and its implications for metabolic health. J. Obes. 2019, 2019, 8031705. [CrossRef]

55. Lee, J.H.; Kim, D.H.; Kim, C.K. Resistance training for glycemic control, muscular strength and lean body mass in old type 2 diabetic patients: A meta-analysis. Diabetes Ther. 2017, 8, 459-473. [CrossRef]

56. Dominguez, L.J.; Barbagallo, M.; Lauretani, F.; Bandinelli, S.; Bos, A.; Corsi, A.M.; Simonsick, E.M.; Ferrucci, L. Magnesium and muscle performance in older persons: The CHIANTI study. Am. J. Clin. Nutr. 2006, 84, 419-426. [CrossRef] [PubMed]

57. Welch, A.A.; Skinner, J.; Hickson, M. Dietary magnesium may be protective for aging of bone and skeletal muscle in middle and younger older mem and women. Nutrients 2017, 9, 1189. [CrossRef]

58. Zhang, Y.; Xun, P.; Wang, R.; Mao, L.; He, K. Can magnesium enhance exercise performance? Nutrients 2017, 9, 946. [CrossRef] [PubMed] 
59. Cameron, D.; Welch, A.A.; Adelnia, F.; Bergeron, C.M.; Reiter, D.A.; Dominguez, L.J.; Brennan, N.A.; Fishbein, K.W.; Spencer, R.G.; Ferrucci, L. Age and muscle function are more closely associated with intracellular magnesium, as assessed by ${ }^{31} \mathrm{P}$ magnetic resonance spectroscopy, than with serum magnesium. Front. Physiol. 2019, 10, 1454. [CrossRef] [PubMed]

60. Huang, W.-Q.; Long, W.-Q.; Mo, X.F.; Zhang, N.-Q.; Luo, H.; Lin, F.Y.; Huang, J.; Zhang, C.-X. Direct and indirect associations between dietary magnesium intake and breast cancer risk. Sci. Rep. 2019, 9, 5764. [CrossRef]

61. Maalmi, H.W.V.; Jansen, L.; Boakye, D.; Schöttker, B.; Hoffmeister, M.; Brenner, H. Association between blood 25-hydroxyvitamin D levels and survival in colorectal cancer patients: An updated systematic review and meta-analysis. Nutrients 2018, 10, 896. [CrossRef] [PubMed]

62. Wesselink, E.; Kok, D.E.; Bours, M.J.L.; de Wilt, J.H.W.; van Baar, H.; van Zutphen, M.; Geijsen, A.M.J.R.; Keulen, E.T.P.; Hansson, B.M.E.; van den Ouweland, J.; et al. Vitamin D, magnesium, calcium, and their interaction in relation to colorectal cancer recurrence and all-cause mortality. Am. J. Clin. Nutr. 2020, 111, 1007-1017. [CrossRef] 